\title{
THE HUMAN CAPITAL OF AN ENTERPRISE: THEORY AND ASSESSMENT METHODOLOGY
}

\author{
Nataliia Pravdiuk', Vitalii Pokynchereda ${ }^{2}$, Maryna Pravdiuk $^{3}$
}

\begin{abstract}
At the present stage of social development, there is a transformation of the persistent views on the place and human role in the economic system. Human capital assets as a set of productive abilities, personal traits, and employee motivation developed as a result of investment become a key factor in the production process, without which any prospects of economic growth are neutralized. The purpose of the article is to provide a theoretical substantiation and systematization of existing methods for assessing human capital, to identify the advantages and disadvantages of their practical application in the enterprise activity, and to develop recommendations aimed at improving the human capital assessment methodology in order to further reflect information on the cost of human capital assets in accounting and reporting of enterprises Methodology. The methodological basis of the study is the historical and logical method used in the study of the economic essence of human capital assets and the evolution of human capital assessment methodology. Dialectical method and comparative analysis have been used to determine the differences between existing human capital assessment methods and to identify positive and negative aspects of their practical application. The methods of scientific abstraction, induction and deduction, analysis and synthesis have been used in developing the methodology for assessing human capital assets and justifying the opportunities for its integration into the accounting and reporting system of the enterprise. Results. It has been established that in international practice, there is a cost-based, profitable, and expert methodology for assessing human capital assets. Based on the analysis of positive and negative aspects of the application of these methods, it is substantiated that from the standpoint of accounting the most cost-based model of human capital assets is the most optimal since it is based on the principle of actual cost peculiar to accounting practice. Taking this into consideration, a cost-based methodology for assessing human capital assets of the enterprise has been suggested, according to which the cost of human capital assets is calculated by capitalizing the costs borne by the employee and the enterprise at all stages of the formation and development of human capital assets, namely, the costs of developing the employee's physical abilities (the cost of developing his/her physical abilities), the cost of training (tuition fee in educational institutions), the cost of obtaining professional experience (the cost of professional experience), and the costs of its professional training (the cost of vocational training in the process of his/her employment). Practical meaning. The introduction of the suggested methodology for assessing human capital assets creates the prerequisites for the subsequent display of information in business accounting and reporting, which in its turn increases the level of informativity of accounting data, promoting to meet the growing needs of external and internal users of information, provides an opportunity to consider the value of human capital in determining the market value of the company. Besides, the suggested assessment methodology enables to produce information about the cost of human capital assets of the enterprise, which is the basis for determining the effectiveness of its use. Value/originality. The suggested methodology for assessing human capital assets creates prerequisites for its implementation in the accounting system of the enterprise, which will create the basis for displaying information about the cost of human capital assets in the enterprise's reporting, which corresponds to the objectives of value-oriented enterprise management.
\end{abstract}

Key words: human capital, human resources, working power, assessment, accounting.

JEL Classification: J24, J41, M41

\footnotetext{
Corresponding author:

${ }^{1}$ Vinnytsia National Agrarian University, Ukraine.

E-mail: npravduyk@gmail.com

${ }^{2}$ Vinnytsia Institute of Trade and Economics of

Kyiv National University of Trade and Economics, Ukraine.

E-mail: vitalii.pokynchereda@gmail.com

${ }^{3}$ Vinnytsia National Agrarian University, Ukraine.

E-mail: a.pravd4449@gmail.com
} 


\section{Introduction}

The internationalization and globalization of the world economy put forward the task of forming a management system capable of responding timely and adequately to the challenges of socio-economic existence, dictated by its transition to the post-industrial stage of social development. Today, it becomes evident that the development of a successful and socially responsible state is impossible without the effective use of human capital. Social and economic development is determined not so much by the perfection of production means, technologies, but by a human being, his/her intelligence, skills, and abilities.

The outcomes of the conducted scientific researches show that at the present time, the cost of knowledge, skills, and abilities accumulated by people exceeds the cost of physical capital. Considering this, the issue of rational management of human capital must become the centre, around which new paradigms of state and corporate governance will be formed. J. Fitz-enz noted: "When we talk to managers about the most important resources, they occasionally point to balance assets. At the same time, they mention people, technologies and information they produce, corporate culture, brand popularity, management ability - all intangible, unrecorded assets" (Fitz-enz, 2006).

Under the present circumstances, not physical capital plays an increasingly important role, as was typical for the industrial age, but the human capital assets, the bearers of which are the population. That is, in the knowledgedriven economy the role of mental labour is increased and the importance of the physically demanding job is reduced, there is a rethinking of the role of human beings from contemplative to the effective factor of production, without which any prospects of economic development are reduced to nothing. As a consequence of this, there is a displacement of the management base from tangible assets to intangible, which is human capital.

Development of human capital theory, formation of methodological provisions for its accounting and assessment became the object of scientific research of many scientists, in particular: T. Arkan (2016), J. Barburski (2012), G. S. Becker (1993), F. Butynets (2010), T. Davydiuk (2011), O. Denysiuk (2016), M. Dobiia (2010; 2012), N. Gudzenko (2017), L. Fernstrom (2010), E. Flamholtz (1982), V. Kalpana (2016), M. Nastenko (2017), J. Roos (2010), S. Pike (2010), V. Pokynchereda (2016; 2017), N. Pravdiuk (2016), O. Sahnenko (2017) et al. The scientific work of the authors is to develop the concept of human capital, as well as to develop theoretical and methodological principles of reflection of human capital in the accounting and reporting of the company. However, giving credit to the scientific achievements of their predecessors, it should be noted that certain aspects related to the formation of methodological approaches to the valuation base of human capital, taking into account the current trends of economic development, need to be systemized and improved.

Works by scientists on economic theory, labour economics and accounting, personal calculations and observations served as an information base of the study. In the process of research, we have used a set of general scientific and special methods of cognition. Studying methodological approaches to the assessment of human capital, the methods of theoretical generalization, grouping, comparison, analysis, and synthesis have been used.

The purpose of the study is to substantiate the theoretical provisions and development of practical recommendations aimed at improving organizational and methodological provisions of human capital assessment under the conditions of operation and development of the post-industrial economy.

\section{Theoretical foundations of human capital assessment}

Under modern conditions, company management should take into account the objective trends of the post-industrial economy, consisting in the prevalence of the role of a human factor over other production factors. If management ignores the real state of affairs in the economy, that leads to destructive changes in the activities of the company, which reflects on its profitability and competitiveness.

Human capital is the centre, around which a system of state and corporate governance must be formed. In this case, the necessary condition for the establishment of effective management of human capital is the creation of an information support system for decision-making, the main role in which belongs to accounting.

When developing the accounting concept of human capital, theorists attach significance to the assessment because it is a central, fundamental element of the accounting method. The assessment, being an integral part and one of the most important elements of accounting, is, at the same time, a complex and multifaceted problem that is further exacerbated when it comes to providing cost measurement for human capital assets.

Difficulties faced by the accountants are related to the difference in the assessment of human capital assets from the conventional method of determining the cost of material objects. Many economists, considering the company resources as the subject of accounting, note that the company's greatest wealth is its personnel, human potential, do not receive due evaluation in the accounting, resulting in its unfitness for economic work. According to the survey conducted by one of the international consulting firms, $95 \%$ of managers of American and European companies recognize the lack of reliable methodology to assess human capital assets, 
and a third of them, in general, indicate the absence of any mechanisms for the implementation of this task (Roos, Pike, Fernstrom, 2010).

Despite the fact that a number of methods for assessing human capital assets have been developed in economic science, at present time, there is no comprehensive holistic approach that would ensure the accuracy of evaluation procedures performed, the ability to record them, and was implemented in accounting standards.

At the same time, representing the human capital of the company in value terms will enable the formation of information that will serve as the basis for assessing the human potential of the company and will promote its effective management. "If you cannot measure anything, it means you cannot manage it", - scientists note (Journal Human Resources, 2008).

The problem of providing cost measurement to employees is not entirely new. In the XVII-XIX centuries, the issues studied were in the centre of scientific interests of the classics of political economy. V. Petty, the founder of the labour theory of value, first tried to give a monetary valuation to a person, noting that "the value of some human individuals is equal to eight-year income brought by them" (Petti, 1940). At the same time, different subjects, according to the researcher, had not the same value. For example, an adult was evaluated by the scientist twice expensive than a child, and the cost of a sailor was three times higher than the "price" of a peasant. The value of the entire population of that time in England was evaluated by V. Petty at about $£$ 417 million, and the cost of each resident amounted to an average of 69 monetary units From simple mathematical calculations of the researcher it follows that the death of 100 thousand people is equal to a loss of almost 7 million pounds sterling for the country (Petti, 1940). In fact, it was the first attempt in the history of economic thought to assess human resources.

A. Smith, the Scotch, another representative of the political economy, when providing a monetary value to an employee took into account the category of wage, which not only included the amount of efforts made and time spent on work performance but also provided remuneration for the efforts made to acquire knowledge that enables successful performance of production tasks. The researcher emphasized that higher wages should be paid for the work of highly skilled employees since they are able to work more productively in comparison with other employees.

In the middle of XX century, F. Knight and I. Fischer came to the conclusion that wages are a percentage of investments in specialist's training while discounting a certain amount of income received, we can calculate the cost of these resources. In this way, according to researchers, we can calculate the cost of capital, land, and human resources. I. Fischer believed that investments made into equipment and in education have much in common, which is to increase future cash flows.
Despite the fact that the ancestors of classical economic theory did not create a common concept for assessing human capital, their best practices became the theoretical basis for the further development of the value theory of human capital, which is in active progress up to the present.

Understanding the importance of human capital in the economic system has led to the emergence of a large range of methods both in the theory and practice for its evaluation, which should be reasonably classified as income-bearing, cost-based, and expert. The costbased method is based on the calculation of the entire set of costs related to the physical and professional development of employees. The income-bearing method involves assessing the value of the product created in the process of implementing the labour potential in the future. Expert methods for determining the value of human capital assets are based on the judgment of a specialist using pre-determined weight coefficients.

\section{The cost-based method of human capital assessment}

A detailed analysis of scientific works of scientists on the assessment of human capital shows that researchers give priority to the cost-based method. At present, this technique is the most studied, to a certain extent, is consistent with the principles of accounting, in particular, the principle of historic (actual) cost. The cost of human capital according to this method is identical to the total cost of its formation, retention, and reproduction. Advantages of using historic evaluation are the following:

- ease of use, which does not require the use of a complex mathematical apparatus;

- a high level of objectivity and reliability since such evaluation is carried out in relation to the events that have already occurred and can be documented, thus depriving the accounting system of predictable and probable indicators.

Most scientists, within the limits of the cost evaluation method, calculate the value of human capital by capitalizing the incurred costs of maintenance, education, and upbringing. That is, human capital is considered in the triad: capital - labour - the remuneration for the work performed. In this case, the salary for the work performed is the notion of measuring the human capital of an employee (Dobiia, Barburski et al., 2012).

In our opinion, the position of researchers, which is based on the identification of the value of human capital with the size of wages and the amount of other social payments, are false. Indeed, at first glance, a highly skilled specialist must claim a higher level of remuneration than an unskilled person. However, under modern conditions, the wage level correlates not only with the qualitative parameters of employees but also 
with the sectoral affiliation of the company, the average level of remuneration, as well as other factors that are not related to the level of personnel training.

Detailed and in-depth coverage of the cost method for assessing human capital was reflected in the scientific works by E. Flamholz, who in due time suggested to assess human capital at the initial (historic) prime cost or at replacement cost (cost of substitution) (Flamholtz, 1982). According to the assessment method suggested by the scientist, the initial cost of human capital includes the costs of its formation and training. The first group of costs includes the company's expenses for the recruitment of personnel (placement of announcement in the media stating about vacancy notices, payment for services of recruitment agencies), selection (testing costs, interviews), expenses for the creation of the workplace, internal displacement, etc. The costs of training include costs for instructions and formal training of employees, their training according to the place of work, loss of productivity in connection with training, etc. Each of these cost groups covers direct and indirect costs that collectively form the initial cost of human capital with subsequent depreciation of this value.
The substitution method evaluates the total cost of human capital through the determination of the value of individual employees. To provide each employee with the cost measurement, they simulate the situation of his dismissal and, at the same time, calculate the total amount of expenses, which includes the cost of substituting the current employee with another, capable of performing the function of the previous one, and the loss of labour productivity during this substitution. The mechanism for the formation of the value of human capital at historical cost and replacement cost is shown in diagram form in Figure 1.

The assessment of human capital, carried out by the method of replacement, in our opinion, will not provide a sufficient level of accuracy of information. Let us suppose, two employees, for the selection, hire and development of which the company incurred identical costs in terms of volume, due to different physiological features and level of preliminary vocational training, will have unequal productivity, and therefore, different value for the subject of economic activity.

Despite many supporters of the cost-based approach to human capital assessment, it should nevertheless be

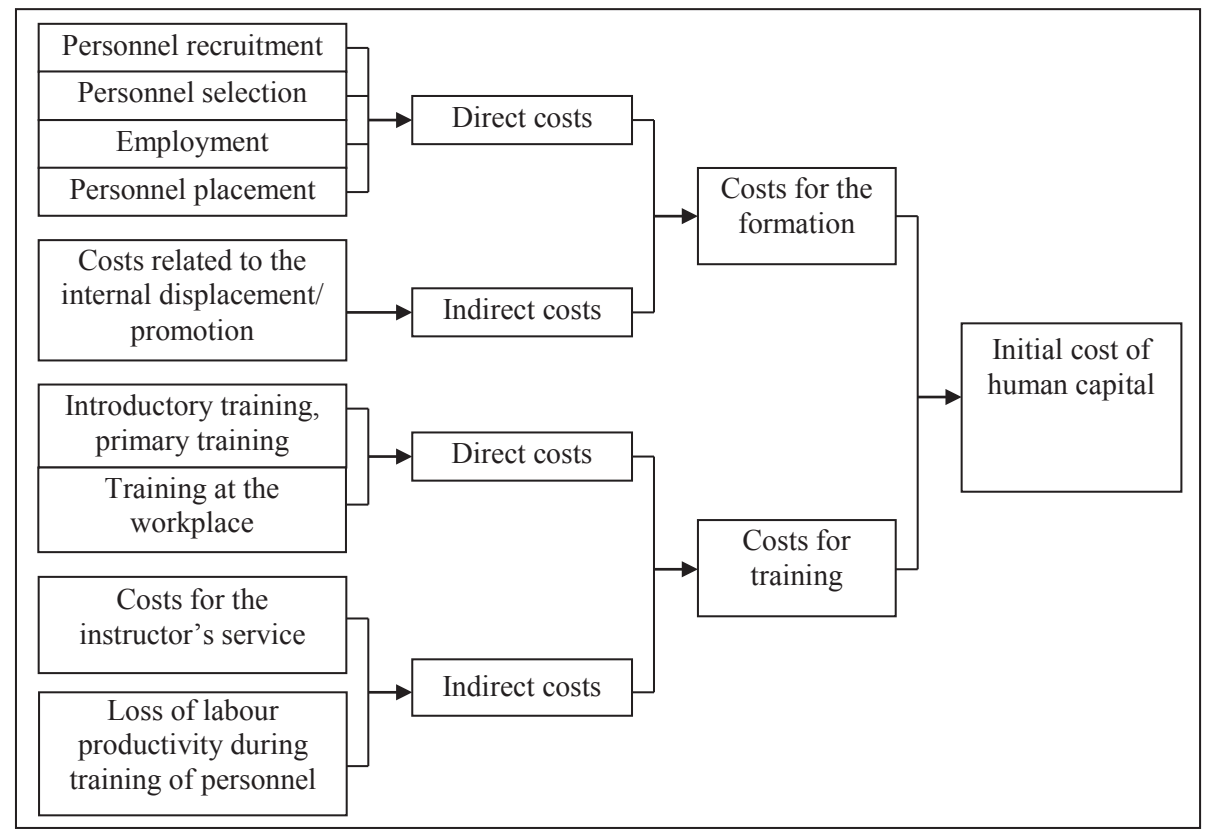

$+$
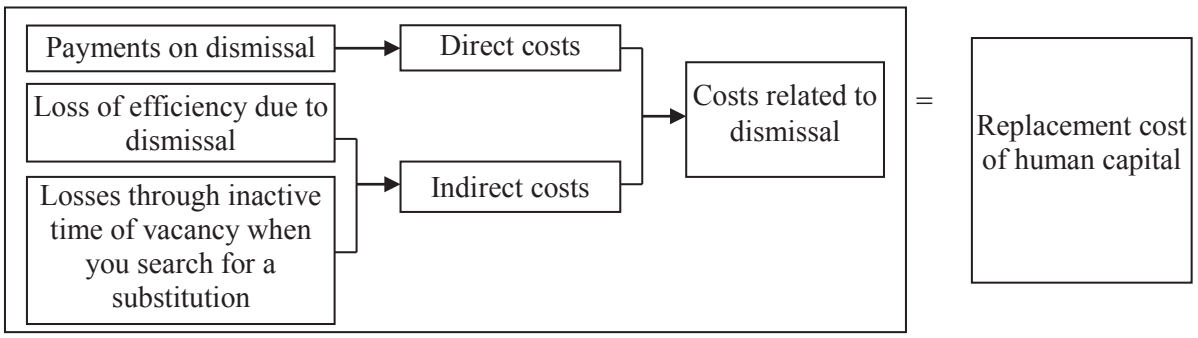

Figure 1. Method of calculation of the initial and replacement cost of human capital

Source: Flamholtz, 1982 
noted that such a method is subjected to constructive criticism from specialists in the field of human resources management. In particular, some economists point to the existence of objective obstacles to its implementation. For example, in practice, it is not always possible to draw a clear line between the costs incurred in forming a labour collective, with the costs involved in supporting and raising the level of skills of employees. One cannot also take into account the risk that the costs incurred by business entities for the formation and development of personnel were partially taken into consideration, and therefore, the calculated human capital cost would be inaccurate. Besides, the scepticism of scientists towards the cost evaluation methodology is explained by the avoidance of qualitative characteristics of personnel. Scientists emphasize that both qualification and experience, being ones of the key characteristics of employees as factors of production in the market economy, unfairly remain outside the evaluation process.

The approach, offered by the group of Polish scientists (Dobiia, Barburski, Gorowski, Koziol, Kurek, 2012) deserves attention within the cost evaluation model. The methodology for assessing human capital, offered by scientists, is based on the assertion that capital does not come from anything but has its origin, which allows giving it a monetary expression. The source of human capital, according to researchers, is an investment in obtaining vocational education, increased by the amount of expenses for the maintenance of an employee. Using the category of property, scientists have offered a formula for calculating the employee's capital, the size of which depends on the amount of initial investments, risk premium, and capitalization period:

$$
H_{t}=H_{0} \cdot e^{p t},(1)
$$

where $H_{t}$ - employee's human capital; $H_{0}$ - initial investments; $p$-risk premium; $t$-capitalization period.

The cost of employee's human capital is the result of the capitalization of the costs of its maintenance and formation. These investments are the source of the employee's ability to perform work, which is improved along with an increase in work experience. At the same time, scientists note that the cost of human capital will be constantly changing since the costs of its formation and professional development have permanent, rather than one-time nature, as it often happens to the financial investments. In view of the abovementioned, the assessment method is presented by the authors in a formalized form:

$$
H(T)=(K+E) \cdot[1+Q(T)],(2)
$$

where $H(T)$ - the cost of employee's human capital; $K$ - capitalized costs for employee's maintenance; $E$ - capitalized costs for obtaining vocational education; $Q(T)$ - time factor.

To calculate the growth of human capital, which is generated in the process of labour activity of each employee, you must take time factor into consideration. Scientists believe that due to cyclicality, recurrence of work, the employee will spend (w) percent less effort on its implementation each successive year. At the same time, the growth of the ability to perform work in the future will have a downward trend. Exactly the procedure for calculating this component when determining the value of human capital, in our opinion, is the main disadvantage of the given methodology. The risk is that the value of experience coefficient depends on the evaluator's subjectivity, which, in its turn, will affect the final estimated value of human capital. However, despite this disadvantage, taking into account the time factor when determining the value of human capital makes it possible to assess its important structural part experience:

$$
Q(T)=1-T^{\frac{\ln (1-w)}{\ln 2}},(3)
$$

where $Q(T)$ - time factor; $w$ - employee's training coefficient; $T$-years of employee's professional activity, $T>1$.

Uncomplicated mathematical transformations make it possible to apply the formula for calculating employee's human capital as the sum of three components:

$$
\begin{aligned}
& H(T)=K+E+D(T) ;(4) \\
& D(T)=(K+E) \cdot Q(T),(5)
\end{aligned}
$$

where $H(T)$ - the cost of employee's human capital; $K$ - capitalized costs for employee's maintenance; $E$ - capitalized costs for obtaining vocational education; $D(T)$ - the cost of employee's experience; $Q(T)$ - time factor.

Agreeing in general with the logic of the scientists referring to the approach to human capital assessment, we believe that the described methodology contains inaccuracies that require elimination through the introduction of certain corrections. In order to do so, we will consider in details the content of each component of the presented evaluation model.

The costs on the employee's maintenance $(\mathrm{K})$ include the investment in the formation of the human body as a carrier of accumulated professional knowledge (abilities, skills) and investment in basic education. Since basic education is free, the total amount of costs is reduced to the capitalized investments in human physical development. Besides, the value of basic knowledge does not matter, as, let's say, professional knowledge. One of the founders of the theory of human capital G. Becker asserted that an employee who has a specific human capital than an employee with the total capital is more valuable for the company (Becker, 1993). We believe that the size of subsistence minimum established by law and accumulated before the beginning of human labour activity can be considered as an investment in the formation of physical abilities of future employees.

The costs of obtaining education (E) are equal to the amount of money invested by the employee in the formation of knowledge required for the performance 
of his/her labour activity. To take into account the quality of specialist's training, we offer aggregate costs on education to be adjusted on the success rate of education calculated on the basis of the average score of academic certificates $(\mathrm{k})$.

Having calculated the influence of time factor (Q $(\mathrm{T})$ ) on the value of human capital by the formula (3), it was established that during the first years of employee's labour activity ( 1 to 5 years depending on the value of training coefficient $(\mathrm{w})$ ), there is a decrease in the value of human capital due to the fact that an indicator (Q $(\mathrm{T})$ ) gains negative value. In our opinion, this position is false because exactly the first years of practical activity are the most valuable. During this period, there is the consolidation of theoretical knowledge and employee's development as a qualified specialist, therefore, the value of human capital should have increased. In order to take into account the position we outlined, we offer to make changes to formula 3. The transformed formula for calculating the factor of experience will have the following form:

$$
Q(T)=1-(1-w)^{T},(6)
$$

where $Q(T)$ - time factor; $w$ - coefficient of employee's training; $T$ - years of employee's professional activity.

Taking into account the best practices of scientists in the part of the human capital assessment and personal perspective to solve this problem, we offer the author's approach to the assessment of human capital. In accordance with the recommended methodology, the total cost of employee's human capital presented through the assessment of his/her qualitative characteristics, namely, physical abilities, education, experience and professional knowledge, must be calculated according to the formula:

$$
H(T)=K+E+D(T)+S,(7)
$$

where $\mathrm{H}(\mathrm{T})$ - the cost of employee's human capital, $\mathrm{UAH} ; \mathrm{K}$ - the cost of physical abilities, UAH; E - the cost of education; $\mathrm{D}(\mathrm{T})$ - the cost of experience; $\mathrm{S}$ - the cost of professional knowledge.

Here is an algorithm for calculating the initial value of employee's human capital through the specification of the methodology for assessing the components of human capital possessed by the employee at the time of his/her acceptance to the company staff (Figure 2).

In the process of conducting business, new technologies are introduced, the manufacturing process is complicated, in general, all activities are carried out under the conditions of an unstable socialeconomic situation. Operation under the conditions of uncertainty requires the employees to master additional technical-economic knowledge formed by their direct participation in conferences, seminars, advanced training courses, etc. The company's costs for personnel training according to their economic content are investments in human capital. Taking into account the foregoing, the cost of professional knowledge (S) as a component of human capital, we offer to make an assessment for the methodology presented in Figure 3.

At the same time, the change in the initial indicators (living wage, length of service, etc.) used when calculating the cost of an employee's human capital, requires a revaluation.

\section{The income-bearing method of human capital assessment}

It should be noted that recently, among the theorists and practitioners, an income-bearing approach to

\begin{tabular}{|c|c|c|c|}
\hline \multicolumn{4}{|c|}{ UE OF EMPLOY } \\
\hline Physical abilities & \multicolumn{2}{|c|}{ Education } & \\
\hline \multicolumn{3}{|c|}{ 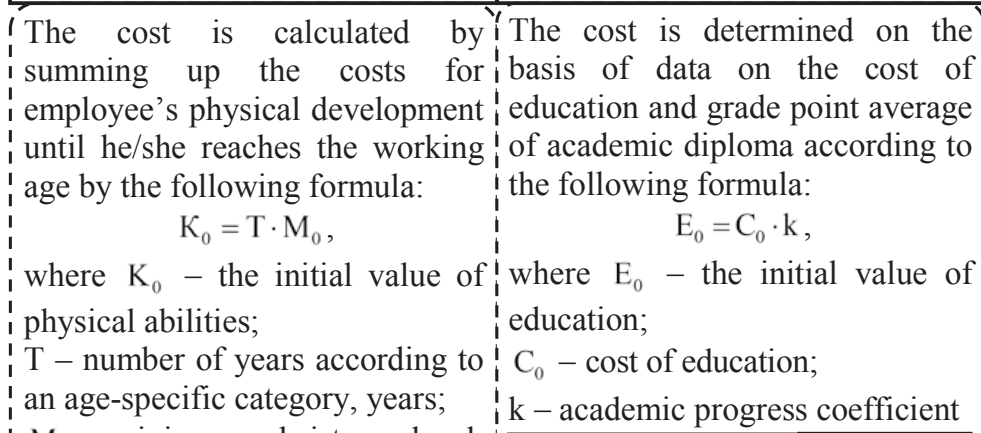 } & $\begin{array}{l}\text { The cost is calculated on the } \\
\text { basis of data on the cost of } \\
\text { education, work experience, and } \\
\text { factor of experience according to } \\
\text { the following formula: } \\
\qquad \mathrm{D}(\mathrm{T})_{0}=\mathrm{C}_{0} \cdot \mathrm{Q}(\mathrm{T})_{0} \text {; } \\
\qquad \mathrm{Q}(\mathrm{T})_{0}=1-(1-\mathrm{w})^{\mathrm{T}_{0}} \\
\text { where } \mathrm{D}(\mathrm{T})_{0}-\text { the initial value } \\
\text { of experience; } \\
\mathrm{C}_{0}-\text { the cost of employee's } \\
\text { training; } \\
\mathrm{W}-\text { training coefficient; } \\
\mathrm{T}_{0} \quad-\text { employee's working } \\
\text { experience, years }\end{array}$ \\
\hline
\end{tabular}
calculate the value of human capital becomes more

Figure 2. Evaluation method of the initial value of an employee's human capital

Source: the author's development 


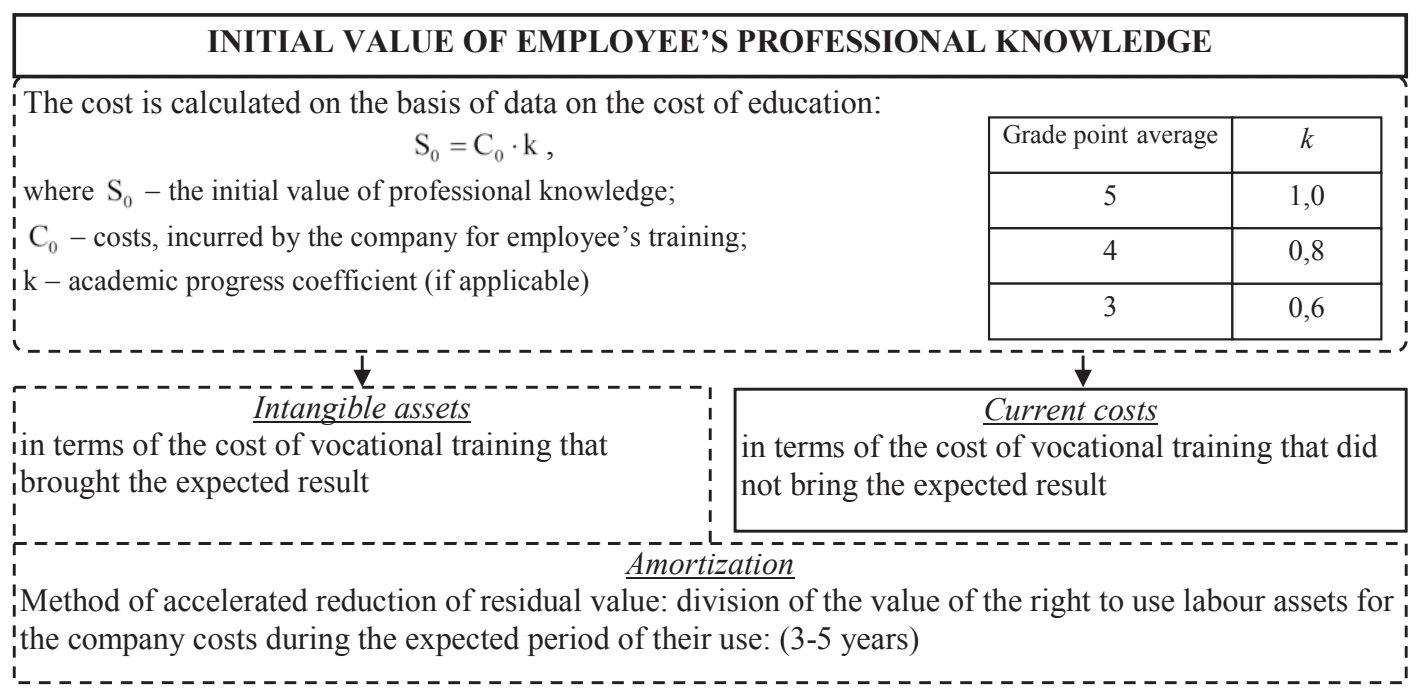

Figure 3. Methodology for evaluating the value of an employee's professional knowledge

Source: the author's development

popular; it is based on the assessment of future potential benefits from its use. Scientists are convinced that this approach is more logical from the standpoint of the economy because it corresponds to the accepted perception of any potential as an opportunity to obtain benefits in the future, and the possible result is related to a qualitative and quantitative component of labour potential.

In accordance with the income-bearing approach, human capital is assessed by the discounting of the future value of income from its use and is calculated by the formula:

$$
D_{c}=\frac{D_{t}}{(1+i)^{t}},(8)
$$

where $D_{c}$ - current income level; $D_{t}$ - future income level; $i$ - current interest rate; $t$ - number of years.

Instead, the practical realization of the incomebearing method encounters significant methodological barriers that are related to the calculation of the overall economic result for the period of using human capital assets. Instead, researchers acknowledge that the practical implementation of the income-bearing method encounters significant methodological barriers that are related to the calculation of the overall economic effect for the period of using human capital assets. This, as noted by the researchers, is due to the fact that the final result of labour potential use is influenced by a significant number of difficult predicted factors, including the pace of technical progress, the level of integration and division of social labour, the level of prices and inflation, structural changes, etc.

T. Davydiuk, having carried out a thorough analysis of the possibility to introduce the income-bearing method for the assessment of human capital, points out to the following disadvantages: firstly, the difficulty in obtaining the initial information for the calculation; secondly, the difficulty in determining the exact amount of income generated by each employee of the company separately; and thirdly, the complexity of establishing a link between knowledge and experience of employees and financial outcomes of the company. Therefore, the entire calculation is based on the future volume of net profit, the value of which is difficult to predict (Davydiuk, 2011).

\section{Expert method of human capital assessment}

We should pay attention also to the expert methodology for assessing human capital, through which you can obtain not less valuable information management. Its main advantage is the maximum consideration of qualitative characteristics of employees, which is the expression of the individual value of a particular employee, the level of his/her professional skills and competence, which collectively form the total cost of the human capital of the business entity. Undoubtedly, the expert methodology corresponds to the logic of understanding the economic role of a person, because in particular employee's qualitative characteristics, such as the ability to think outside the box, the ability to apply the accumulated knowledge, skills, and experience contribute to better orientation in atypical business situations and the adoption of optimal solutions. However, expert evaluation of company human capital has a significant disadvantage - subjectivism. The calculated cost of human capital will depend to a certain extent on the knowledge, skills, and will of the evaluators. And this, in its turn, can affect the correctness of managerial decisions taken on the basis of such information.

Thus, the most optimal way from the perspective of the possibility of adapting to the accounting system of the company is the cost-based methodology for 
assessing human capital, which mainly serves the purposes of financial and managerial accounting, while the income-bearing and expert methods of assessment are limited to managerial accounting.

\section{Conclusions}

Under the conditions of a post-industrial economy, human capital is the most important strategic resource of the company. Employees, their knowledge, experience, and qualification make a decisive contribution to ensure the progressive promotion of business entities, raising their levels of profitability and investment attractiveness. Under these conditions, approaches to human capital management need to be improved, which is possible by the high-quality accounting and information provision of the management process, which is mainly based on the value terms of labour resources.

According to the outcomes of the conducted study, it was found that in the scientific literature, there are three methods for evaluating human capital assets, grouped by cost-based, income-bearing, and expert approaches.
Based on the analysis of positive and negative aspects of existing methods, it has been substantiated that from the standpoint of accounting, the most optimal is a cost-based model of human capital assessment since it is based on the principle of actual cost proper for accounting theory and practice. Taking into account the achievements of scientists, we have presented the approach to the evaluation of employee's human capital, on the basis of which the cost is calculated by summing up the costs for its creation, namely, the costs for the formation of employee's physical abilities, the costs of obtaining education, the costs of experience and expenses for vocational training of the employee in the process of his/her labour activities.

Practical implementation of the suggested costoriented methodology for assessing human capital is an important tool for quantifying the cost of personnel of the company, which will ensure its subsequent reflection in the system of accounting and reporting. The success of the company business will be correlated with the rationality of personnel management, which will be based on a reliable assessment of human capital.

\section{References:}

Arkan, T. (2016). Human Resources Accounting: A Suggested Model for Measurement and Valuatio. Finanse, Rynki Finansowe, Ubezpieczenia, 1(79), 173-193. Retrieved from: https://wneiz.pl/nauka_wneiz/frfu/ 79-2016/FRFU-79-173.pdf

Becker, G. (1993). Human Capital: A Theoretical and Empirical Analysis (with Special Reference to Education). Chicago and London.

Butynets, F., Dobiia, M. et al. (2010). Teoryia izmerenyia kapitala i prybyli. Krakow: Fundacja Uniwersytetu Ekonomicznego w Krakowie.

Denysiuk, O., Pokynchereda, V. (2016). Ozinka liudskoho kapitalu. Visnyk Kyivskoho natsionalnoho torhovelnoekonomichnoho universytetu, 1(105), 109-121. Retrieved from: http://visnik.knteu.kiev.ua/files/2016/01/9.pdf Dobiia, M., Barburski, J. et al. (2012). Chelovecheskiy kapital v ekonomicheskoy perspektive. Kyiv: Kondor.

Fitz-enz, J. (2006). Rentabelnost investitsiy v personal: izmerenie ekonomicheskoy tsennosti personala. Moskow: Vershina.

Flamholtz, E. (1982). Rechnungslegung über Kosten und Wert des Humankapitals; in: Schmidt, H., Humanverzögerungsrechnung, Berlin, New York.

Kalpana, V. (2016). Human Resource Accounting in Indian Companies - Importance and Challenges. International Journal of Scientific Engineering and Research (IJSER), 4(5), 15-18. Retrieved from: http://www.ijser.in/archives/ v4i5/IJSER15788.pdf

Petti, V. (1940). Ekonomicheskie i statisticheskie raboty. Moskow: Gosudarstvennoe socialno-ekonomicheskoe izdatelstvo.

Pokynchereda, V., Gudzenko, N., Nastenko, M. (2017). Human resource accounting in the system of value-based business management. Retrieved from: https://businessperspectives.org/journals/investment-managementand-financial-innovations/issue-2-cont-12/human-resource-accounting-in-the-system-of-value-based-businessmanagement

Pravdiuk, N., Pokynchereda, V. (2016). Trudovi resursy pidpryiemstv: oblikovo-analitychne zabezpechennia upravlinnia: monohrafiia. Vinnytsia: PP “TD "Edelveis i K”.

Roos, J., Pike, S., Fernstrom, L. (2010). Intellektualnyiy kapital: praktika upravleniya. Saint Petersburg: Visshaya shkola menedzhmenta.

Sahnenko, O. (2017). Metody otsinky liudskoho kapitalu. Ekonomika i suspilstvo, 10, 24-27. Retrieved from: http://economyandsociety.in.ua/journal/10_ukr/5.pdf

Stein, D. (2010). Bilanzierung von Humankapital. Grundlagen und Möglichkeiten für die unternehmerische Praxis. Köln.

The official website of the journal "Human Resources" (2008). "Measure - control means". Retrieved from: http://otdelkadrov.by/number/2008/7/izmerayt-upravlya 